\title{
DE INDUSTRIEELE „TRUSTS” DER VEREENIGDE STATEN VAN AMERIKA.
}

I.

De groote industrieele corporaties in de Vereenigde Staten van Amerika zijn het natuurlijk gevolg van de ontwikkeling der nijverheid aldaar. Ze moeten beschouwd worden als de natuurlijke uitkomst der beweging, welke dringt tot de grootst mogelijke besparing van roortbrengingskosten.

Aldus ten minste het oordeel over haar van de voorstanders in Amerika zelf.

En let men op de jongste phase in de geschiedenis dier corporaties zoo wordt men er werkelijk door getroffeu, dat in het telkens nieuwe vorderingen maken der beweging een zekere noodwendigheid scheen gelegen te zijn.

Is echter daarmede nu ook bewezen dat de beweging eene gezonde is, dat door de samenvoeging, telkens en telkens meer, van verschillende bedrijven onder é́n bestuur, feitelijk, zoo dan a] niet vormelijk, eigenlijk tot éne onderneming, het daarbij voorop gestelde doel bereikt zal worden?

Wordt dit inderdaad veelal beweerd, anderzijds wordt het niet minder krachtig betwist. En daarbij wordt rooral ook gewezen op groote nadeelen, welke tegenover de roorgespiegelde voordeelen zouden staan.

Het mag daarom van belang geacht worden eens nader de aandacht te vestigen op hetgeen in den laatsten tijd over het onderwerp is gezegd en geschreven. Te ontreinzen valt het toch niet, dat men hier te doen heeft met eene beweging op economisch gebied van zoo groote beteekenis dat, zoowel wat betreft de theoretische zijde van het vragistuk als de practische gevolgen, zij niet slechts van lokaal belang is. Bovendien is de kwestie ook buiten Amerika zelf in én opzicht van direct EcoN. 1901. 
practische beteekenis, namelijk door de verspreiding van de aandeelen der nieuwe corporaties almede op de Europeesche markten. Zoodoende toch zijn velen direct belanghebbend bij de vraag, of die moderne Amerikaansche corporaties de toekomst voor zich hebben dan wel haar bestaan bedreigd wordt, of dat althans, overmijdelijk, zij ten aanzien harer organisatie en der voorwarden waronder ze bestaan, wijzigingen zullen moeten ondergaan.

In de eerste plaats moge hier, intusschen, herinnerd worden aan de feiten zelven betreffende het jongste verloop der beweging.

Ik bedoel echter mij daarbij te bepalen - mogelijk is het niet overbodig het uitdrukkelijk te zeggen — tot de bedoelde beweging in de Vereenigde Staten wat betreft de eigenlijke nijverheidsbedrijven. Men weet dat eene soortgelijke beweging ook valt waar te nemen op het terrein van spoorweg-exploitatie. Maar al zijn daaarbij punten van overeenkomst op te merken, de verschillen zijn nog grooter. Het zal goed zijn beide zaken niet dooreen te mengen. Bindelijk zou er ook nog op eene derde beweging van soortgelijken aard, eene beweging van concentratie, van samenvoeging van onderscheidene instellingen onder ééne leiding, te wijzen zijn, namelijk op het gebied van het bankwezen. Doch, daargelaten dat hier de beweging nog van slechts zeer recenten datum is, eigenlijk eerst eenige voorloopige teekenen van leven begint te geven, zou bij deze zeker nog in ruimere mate meer op punten van verschil dan van overeenkomst te wijzen zijn. Het is mogelijk dat wij bij de drie genoemde bewegingen te doen hebben met kinderen van één geest, uitingen van éne richting, toch zouden ze ieder eene afzonderlijke behandeling vereischen.

Bovendien, ons onderwerp is reeds omvangrijk genoeg, en zelfs zó6 beperkt opgevat zullen wij toch ons in hoofdzaak moeten bepalen tot éne typische yiting der beweging.

Ter zake dan.

In Maart 1.l. werd opgericht de United States Steel Corporation.

Gewend als onze tijd is geworden aan groote cijfers, betrof het evenwel bij deze stichting een kapitaal zób aanzienlijk, dat daarin alleen een aanleiding bestond om de algemeene aandacht te trekken ook buiten Amerika. Het kapitaal der corporatie toch, aandeelen- en obligatienkapitaal te samen genomen, bedraagt 
niet minder dan 1404, millioen dollars, ruim $3 \frac{1}{2}$ milliard guldens.

En men weet dat bij de Amerikaansche corporaties of "Trusts" - om dezen algemeenen term te gebruiken - het niet geldt, zooals bij de voornamelijk in Duitschland en Oostenrijk bekende kartels, de samenwerking of verstandhouding ten aanzien van ééne handeling van versuhillende instellingen of inrichtingen, die echter overigens ieder hare volkomen zelfstandigheid bewaren, maar wel degelijk de samensmelting tot één geheel van de verschillende vereenigd wordende bedrijven. Wettelijk blijven bij de tegenwoordige Amerikaansche corporaties die bedrijven wel in hun oude bestaan gehandhaafd, maar feitelijk verdwijnen ze en maken ze plaats voor de reuzen-instelling die ze opslokt met absolute énnheid van bestuur.

De United States Steel Corporation nu is, wat dit betreft, geheel van denzelfden aard als de talrijke corporaties welke reeds voor haar werden opgericht. Alleen maar is ze, ten eerste, nog veel grooter, veel reusachtiger dan eenige andere der oudere industrieele corporaties. En ten tweede bestaat er tusschen haar en hare zuster-instellingen het volgende verschil. De vroegere corporaties werden, hoofdzakelijk althans, gevormd door de bijeenvoeging van gewone maatschappijen of particuliere ondernemingen ; maar de United States Steel Corporation werd gevormd door een nieuwe samenvoeging van reeds tevoren tot stand gekomen soortgelijke instellingen. In haar toch werden vereenigd, behalve de gansch eenig in haar soort geweest zijnde Carnegiemaatschappij - en eigenlijk was ook deze reeds een eigen trust-corporatie - aanvankelijk zeven corporaties en later nog twee andere, welke ieder harer reeds door de samenvoeging van een aantal bestaande instellingen waren gevormd en dat wel, het verdient opmerking, met een enkele vitzondering, in de laatstroorgaande drie jaren.

De United States Steel Corporation heeft ten doel de exploitatie van het gansche arbeidsveld van de ijzer- en staalindustrie in de Vereenigde Staten.

Op dit gebied nu bestonden er in de Vereenigde Staten op het eind van het vorige jaar een 29-tal trusts of corporaties met een gezamenlijk aandeelen-kapital van 944.045 .54 .9 doll., welke te zamen beheerden 448 rroeger afzonderlijk bestaan hebbende installaties of bedrijven. 
Ziehier de opgave dezer 29 corporaties ${ }^{1}$ ). Wij hebben er de datums van oprichting bijgevoegd. Voorts zij daarbij nog aangeteekend dat, gelijk ook weder de United States Steel Corporation, alle zijn opgericht onder de wetten van den staat New Jersey, met uitzondering van de Virginia Iron, Coal and Coke Co, die haar arbeidsveld alleen in Virginia hebbende onder de wetten van dien staat tot stand kwam.

Van de hier genoemde 29 corporaties zijn nu het door ons in de eerste plaats vermelde negental, met een gezamenlijk aandeelenkapitaal $\operatorname{van} 549.282 .249$ doll., in de U. S. S. C. opgegaan en dat wel de eerste zeven onmiddellijk bij hare oprichting, de twee volgende korten tijd daarna. Voorts werd, als reeds gezegd, in haar opgenomen de Carnegie Maatschappij; deze ook dadelijk bij de oprichting.

De bezittingen, vertegenwoordigd door de Carnegie Maatschappij en door de zeven eerstgenoemde corporaties, omvatten :

78 Hoogovens,
149 Staalfabrieken voor verschillende doeleinden, als staal-, platen, staaldraad-, nagel- en blikfabrieken,

6 fabrieken voor fijnere artikelen, met een gezamenlijke capaciteit v. 9.000.000 ton fabrikaat.

18300 coke ovens, 70830 acres steenkolenvelden,

1) Het nevenstaande staatje is in hoofdzaak ontleend aan een rapport, dat de belanghebbenden bij de ijzerindustrie te Charleroi lieten opmaken over den toestand dezer industrie in de Vereenigde Staten, en waarvan een extract is opgenomen in het onlangs verschenen werk van den heer G. Villain sLe fer, la houille et la métallurgie á la fin du XIX siècle.x Dit andere bronnen is het echter eenigszins angevuld en zijn daarin ook eenige correcties aangebracht; zoo was b. v. in genoemd rapport als het kapitaal der corporaties vermeld datgene tot de uitgifte waarvan zij gemachtigd waren in plaats van het werkelijk uitgegevene, en dit is thans verbeterd. Z66 als het nu luidt zal het allicht nog niet op absolute volledigheid kunnen bogen - zoo kan er altijd één verschilpunt bestaan t. w. in de appreciatie of een bedrijf van toegepaste ijzeren staalindustrie al of niet tot dien tak van nijverheid behoort maar het zal thans toch genoegzaam juist geheeten mogen worden. 

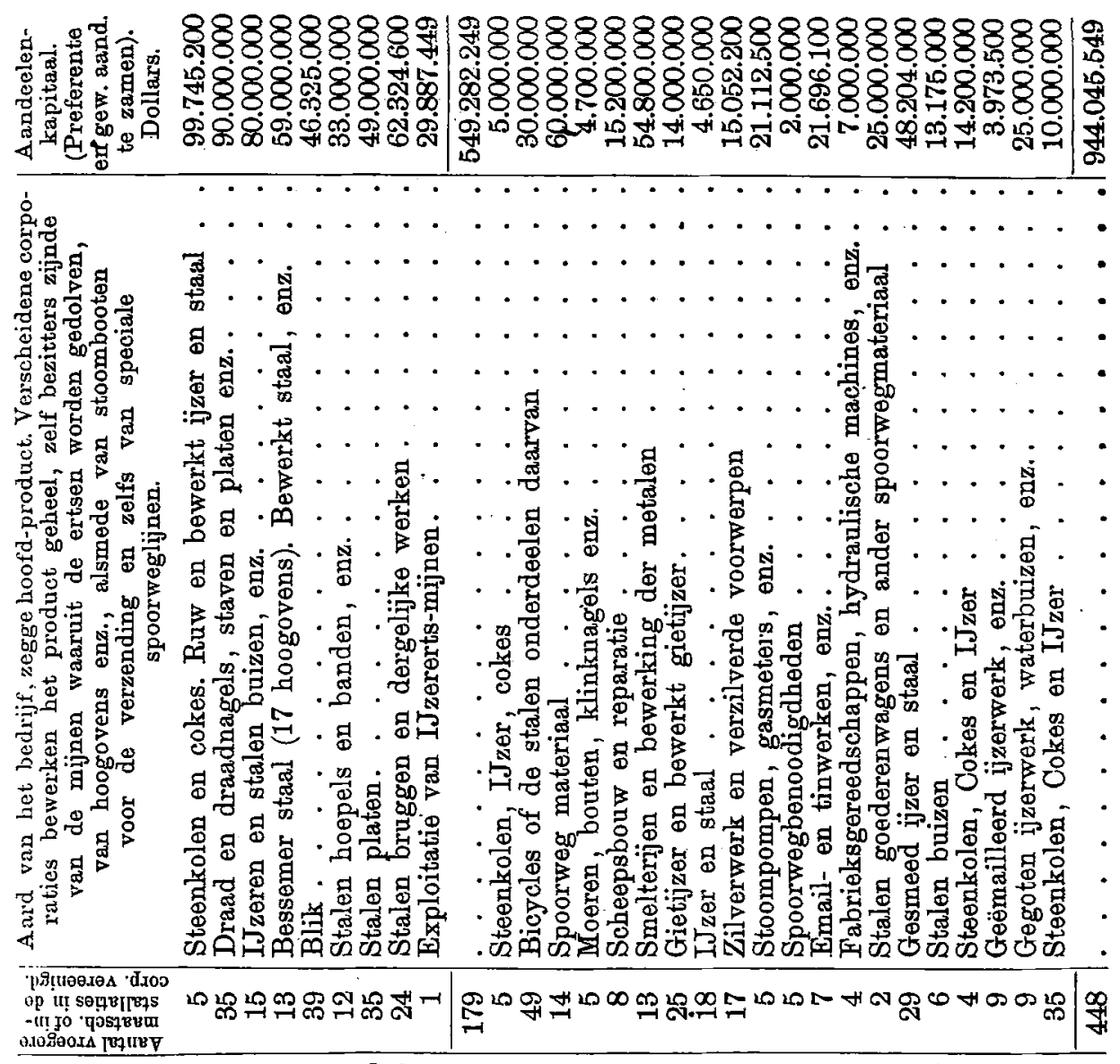

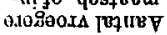

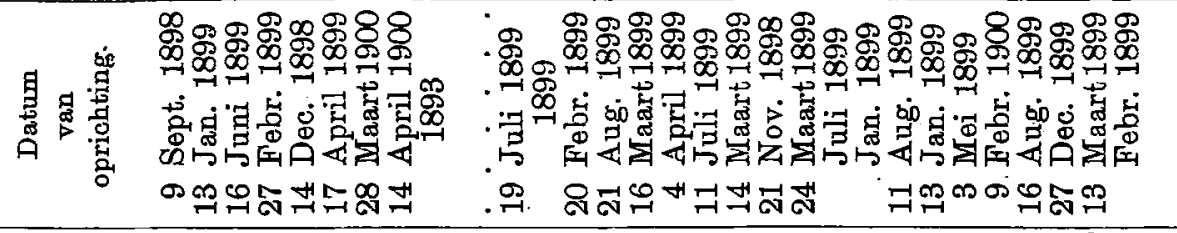

'

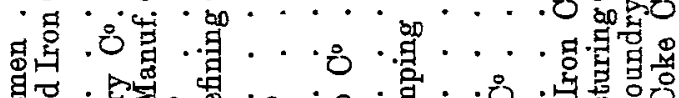
覃.

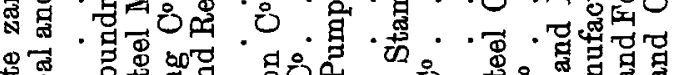

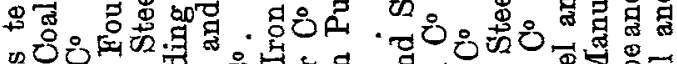

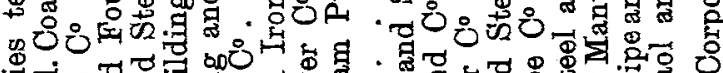

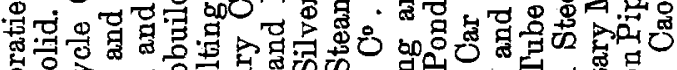
ㄴㅇㅇ

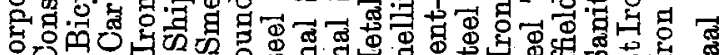
రั0

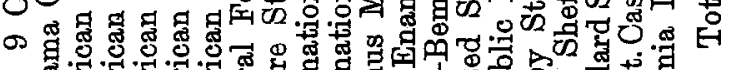

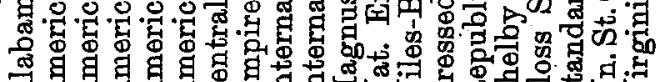

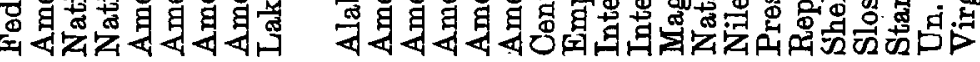


en onderscheidene ijzermijnen met een jaarlijksche capaciteit van 11.000 .000 ton erts, voorts een vloot van 66 vaartuigen voor het vervoer over de meren, en een zeker aantal kleine spoorweglijnen.

Door de opname der laatstgenoemde twee corporaties kwam de U. S. S. C. verder in het bezit van al de fabrieken der Bridge $C^{\circ}$ met een gezamenlijke capaciteit van 600.000 ton fabrikaat per jaar, alsmede van de zeer belangrijke jjzermijnen der Lake Superior Consolidated Iron Mines, welke trouwens ten deele reeds aan de Carnegie Maatschappij verpacht waren.

De overgang van de oude corporaties en van de Carnegie Maatschappij heeft plaats gevonden, door de bemiddeling van een syndicaat onder leiding van de firma J. P. Morgan en $\mathrm{C}^{\circ}$., door verwisseling van hare aandeelen en wat betreft de Carnegie Maatschappij ook van hare obligatien, tegen aandeelen en obligatien van de nieuwe corporatie. Het kapitaal vau deze werd vastgesteld op

550.000.000 doll. 7 pCts Cumulatieve Preferente aandeelen.

550.000 .000 "Gewone aandeelen en

$304.000 .000 " 5$ pCts. Goud-obligatien.

De voet waarop de verwisseling plaats vond was voor de onderscheidene corporaties verschillend. Welke die voorwaarden waren voor de Carnegie Maatschappij is eigenlijk nooit publiek gemaakt. Maar de "Industrial Commission," de staats-commissie aan welke door de regeering der Vereenigde Staten werd opgedragen een onderzoek in te stellen naar de organisatie en de werking der. industrieele trusts, heeft toch, door de bij haar ingekomen inlichtingen, van de kapitaals-vorming van de United States Steel Corporation een volledig overzicht kunnen geven, dat zij acht genoegzaam accuraat te zijn.

Wij laten dit overzicht bier nu volgen ${ }^{1}$ ). .

1) Het tweede rapport der bovengenoemde commissie is nog niet in druk verschenen. Door bijzondere omstandigheden heeft schrijver echter inzage kunnen bekomen van de schoone proefbladen van dit rapport, waarin bedoeld overzicht voorkomt. De kennis van nog verschillende andere bijzonderheden, die verder vermeld zullen worden, dankt hij evenzeer daaraan. 


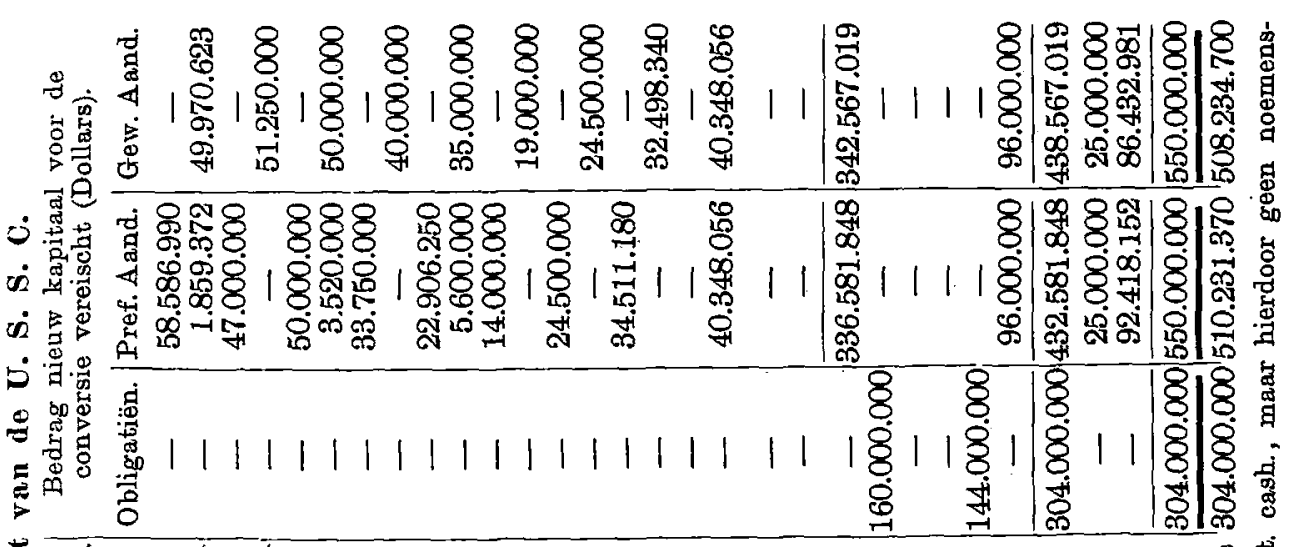

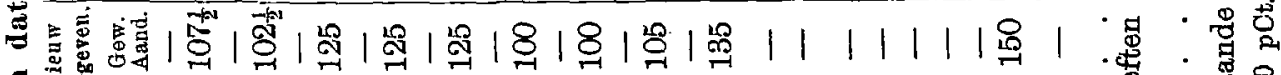

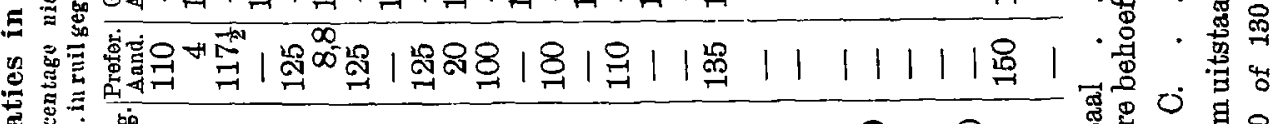

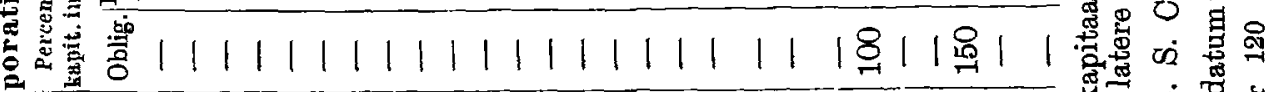

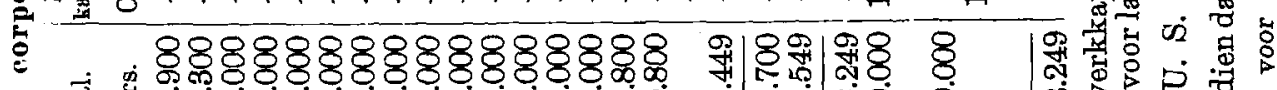

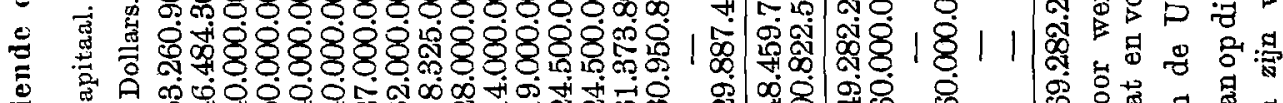

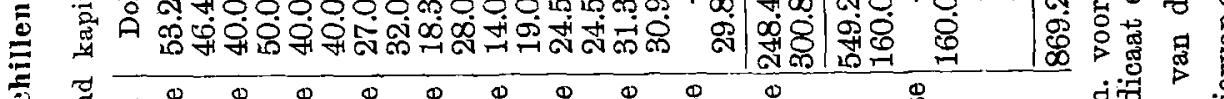

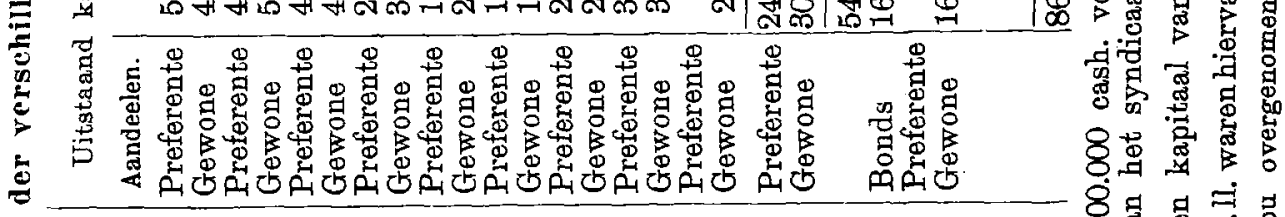

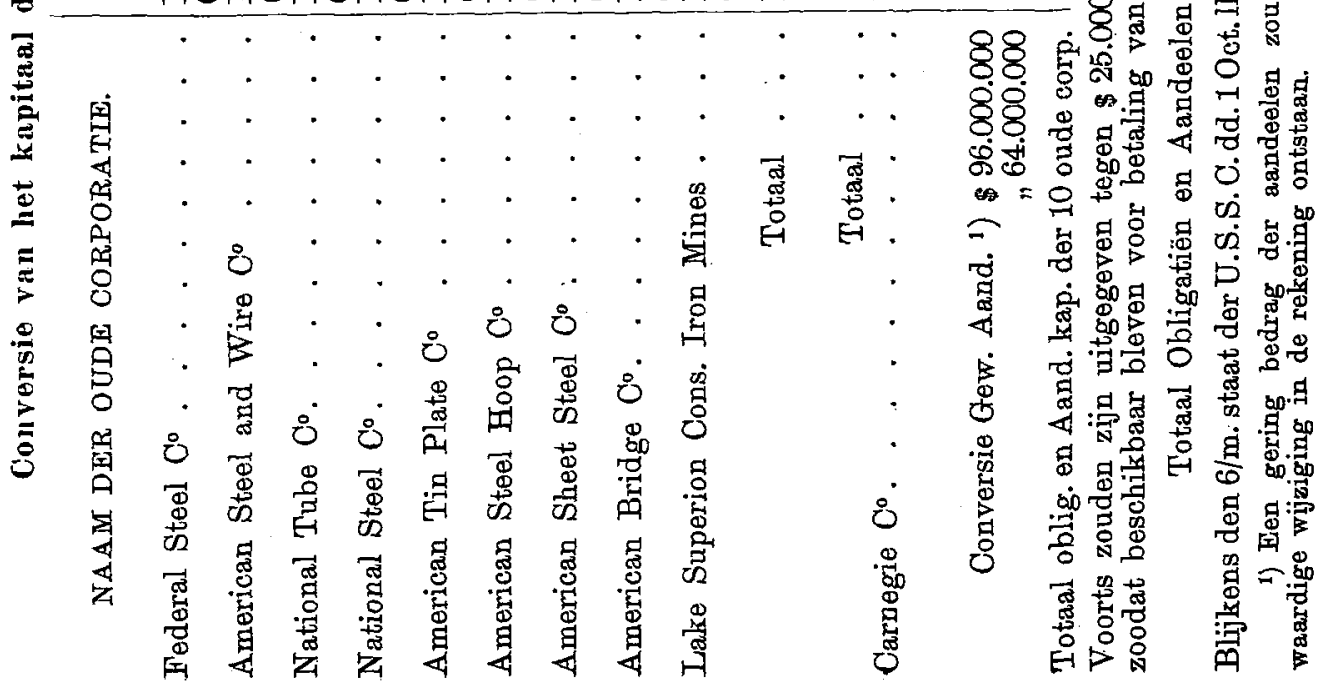


Tolledigheidshalve zij verder opgemerkt, dat de Federal Steel Company behalve haar aandeelen-kapitaal ook een obligatienkapitaal had van 26.806.000 doll. en door de American Steel and Wire Company 5.630.0100 doll. Stoomvaart-obligatien gegarandeerd waren. De uit dien hoofde voortspruitende verplichtingen zijn blijven bestaan. Overigens echter hadden de negen oude corporaties welke thans in de U. S. S. C. zijn overgegaan geen obligatien-kapitaal, rustten op haar dus geen vaste lasien. Bij de beoordeeling van de financieele positie der nieuwe corporatie is dit een punt van veel gewicht.

Daartegenover staat evenwel dat de preferente aandeelen der U. S. S. C. een 7 pCts. cumulatieve preferentie hebben, gelijk trouwens ook reeds het geval was ten aanzien van de preferente aandeelen der oude corporaties, behalve van die der Federal Steel Company, welke 6 pCts niet-cumulatieve waren. In het algemeen worden in Amerika cumulatieve preferente aandeelen beschouwd als een last leggende op de maatschappij die ze uitgeeft, weinig verschillende van dien welke ontstaat uit obligatienkapitaal. Eén onderscheid is er, t. $w$. dat bij niet betaling der rente op het obligatienkapitaal, de obligatiehouders kunnen overgaan tot executie der maatschappij en het bestuur in hunne handen kunnen nemen, in welke positie de houders van preferente aandeelen niet komen bij de niet uitbetaling van het dividend. Doch wanneer op cumulatief preferente aandeelen het dividend niet wordt betaald, vermindert de kans op toekomstige dividenden voor de gewone aandeelen zoozeer, dat deze schier waardeloos worden; en daarom zal eene maatschappij, voor welke het niet volkomen onverschillig is in welke positie zij de houders harer gewone aandeelen brengt, zich al niẹt minder beijveren het dividend uit te betalen op cumulatief preferente aandeelen dan de rente op obligatien; om zulks te kunnen doen, in het eene geval niet minder dan in het andere, liever afschrijvingen en verbeteringen achterwege laten dan met de uitbetaling in gebreke te blijven.

De Carnegie $C^{o}$ had, als in ons staatje aangegeven, een 5 pets. obligatienkapitaal van 160.000 .000 doll. en daarvoor, alsmede in conversie van een deel van haar aandeelenkapitaal, is thans bij de United States Steel Corporation in de plaats getreden een 5 pCts. obligatienkapitaal van 304.000.000 doll. 
Verder staat nu bij de United States Steel Corporation tegenover het niet-preferente aandeelenkapitaal van de Carnegie $C^{\circ}$., groot 160.000 .000 doll., een preferent en een gewoon aandeelenkapitaal ieder van 96.000.000 doll.

In het geheel heeft dus de overgang in de United States Steel Corporation van de negen oude corporaties geleid tot eene vermeerdering van het preferente aandeelenkapitaal van 248.459 .700 doll. tot 336.581.848 doll. dat is met . . . . 88.122.148 doll.

en van het gewone aaudeelenkapitaal vau 300.822 .549 doll. tot 342.567.019 doll. d. i. met. . . . . 41.7444.470 doll. en die van de Carnegie $\mathrm{C}^{n}$. tot eene vermeerdering van het obligatienkapitaal van 160.000 .000 doll. tot 304.000 .000 doll. d. i. met . . . . . . . . . . . . 144.000.000 doll.

en van het preferente aandeelenkapitaal van nihil tot 96.000.000 doll. d. i. met . . . . . . 96.000.000 doll. deze daarentegen tot eene vermindering van gewoon aandeelenkapitaal van 160.000 .000 doll. tot 96.000 .000 doll. d. i. met. . . . . . . . . . . . . . 64.000.000 doll. makende te zamen, vermeerdering obligatien-kapitaal 144.000 .000 doll.

dito preferent aandeelenkapitaal . . . $\frac{.184 .122 .148 \text { doll. }}{\text { te }}$ af vermindering gewoon kapitaal:

vermindering. . . 64.000.000 doll.

vermeerdering . . . 41.744.470 " 22.255.530 doll.

Saldo totale kapitaalsvermeerdering ..$\overline{305.866 .618}$ doll. behalve de vermeerdering ontstaan door de noodzakelijkheid om nieuw werkkapitaal te verkrijgen, en die ter betaling van het syndicaat dat de conversie heeft bezorgd.

Wat betreft de verhouding der vaste lasten tusschen den vroegeren toestand en den tegenwoordigen, zoo is de rekening als volgt. Wiel te verstaan, de betaling van het cumulatieve preferente dividend beschouwd wordende als te behooren tot de vaste lasten. Daarentegen was het billijk in deze berekening nu ook op te nemen, als waren het vaste lasten geweest van de oude corporatien, 7 pct. zoowel over het gewone aandeelenkapitaal van de Carnegie $C^{\circ}$. als over dat van de Lake Superior Cons-Iron Mines, omdat deze beide maatschappijen geen preferent aandeelenkapitaal hadden. 


\section{2}

Oude corporaties. Preferent kapitaal. Dividend. Bedrag. dollar. pCt. dollar:

\begin{tabular}{|c|c|c|c|c|c|}
\hline Federal Steel & $\mathrm{C}^{0}$ & & 53.260 .900 & 6 & 3.195 .654 \\
\hline Am. Steel and Wire & $"$ & & 40.000 .000 & 7 & 2.800 .000 \\
\hline National Tube & $"$ & - & $4,0.000 .000$ & 7 & 2.800 .000 \\
\hline National Steel & $"$ & & 27.000 .000 & 7 & 1.890 .000 \\
\hline Am. Tin Plate & $"$ & & 18.325 .000 & 7 & 1.282 .750 \\
\hline Am. Steel Hoop & $"$ & • & 14.000 .000 & 7 & 980.000 \\
\hline Am. Sheet Steel & $"$ & & 24.500 .000 & 7 & 1.715 .000 \\
\hline Am. Bridge & $"$ & & 31.373 .800 & 7 & 2.196 .166 \\
\hline
\end{tabular}

L. Sup. Cons. Iron Mines. 29.887.449 stelle 7 2.092.12] Carnegie C. . . . . . 160.000 .000 " 710.200 .000 Obligatien. Idem . . . . . 160.000.000

U. S. S. C. Pref. kap. 432.581.848 Idem Obligatien 304.000 .000

$\begin{array}{cr}5 & 8.000 .000 \\ \text { totaal } & 37.151 .691 \\ 7 & 30.280 .729 \\ 5 & 15.200 .000 \\ \text { totaal } & 45.480 .729 \\ . & 8.329 .038\end{array}$

Maakt vermeerdering van vaste lasten . . . 8.329 .038

En indien men het aangenomen dividend voor de gewone aandeelen L. Sup. Cons. Iron Mines en voor de Carnegie Co niet onder de vaste lasten zou opnemen, dan werd dit cijfer zelfs 20.621.159 doll.

Moet nu echter hieruit besloten worden dat bij de oprichting der U. S. S. C. over-kapitalisatie heeft plaats gevonden?

Die vraag op haarzelve is van zeer groot gewicht. Ze kan echter door de verwijzing naar de vermelde cijfers, zonder meer, niet beantwoord worden. Immers, dat door de vereeniging van onderscheidene bedrijven tot één geheel er eene verbetering zou kunnen plaats vinden van de voorwaarden waaronder de bedrijven worden uitgeoefend, daardoor dus, uit het oogpunt der rentabiliteit, waarde-vermeerdering der onderneming zou kunnen ontstaan, het is a priori niet tegen te spreken. Dat dit verwacht mag worden, omdat uit de concentratie der bedrijren vermindering van voortbrengingskosten zou voortvloeien, het is, integendeel, juist wat door de voorstanders der beweging wordt beweerd.

Doch allereerst dient nu, naar het voorkomt, onderzocht 
te worden hoe het stond ten opzichte van de kapitalisatie der oude corporaties welke zich in de United States Steel Corporation hebben opgelost. Alsook welke hare positie was vóór de laatste samensmelting.

Aangaande de kapitaalsvorming van de zeven corporaties, die dadelijk bij de oprichting van de United States Steel Corporation in deze overgingen, zijn door vroegere bestuurders belangrijke mededeelingen gedaan an de Industrial Commission en door deze opgenomen in het rapport, waaraan wij reeds den algemeenen conversie-staat betreffende de vorming der United States Steel Corporation ontleenden.

Ten aanzien van de American Tin Plate $C^{\circ}$. waarvan de 18.325.000 doll. pref. aand. i25 pCt. nieuwe pref. aand. ontvingen en de 28.000 .000 doll. gew. aand. 20 pCt. nieuwe pref. en 125 pCt. nieuwe gewone aandeelen -- werd gezegd, dat de 18.325.000 doll. pref. aandeeleu geacht waren geworden de verkoopswaarde te vertegenwoordigen der ingebrachte installaties als in exploitatie zijnde bedrijven, het gewone aandeelenkapitaal daarentegen uitsluitend "good will", gunstige verwachtingen voor de toekomst, en de betaling aan de oprichters der nieuwe corporatie. Nog werd daarbij gevoegd, dat de overdracht had plaats gevonden op een tijdstip dat de zaken zeer goed gingen en dat de installaties dan ook hoog getaxeerd waren, zoozeer dat het totale aandeelenkapitaal wel drie of viermaal de verkoopwaarde onder gewone omstandigheden had bedragen. Wij kunnen intusschen niet nalaten op te merken dat het ons voorkomt, alsof deze getuigenis werd afgelegd door een oud-bestuurder, die tegenover de tegenwoordige waardeering der zaak de vroegere overdracht wilde verdedigen.

Van de National Steel $\mathrm{C}^{\circ}$. - waarvan de preferente aandeelen a 125 pCt. in nieuwe preferente, de gewone aandeelen à 125 pCt. in nieuwe gewone aandeelen zijn overgegaan - werd ook getuigd, dat de waarde der verschillende installaties moest aangenomen worden als tegen de 27.000 .000 doll. preferent aandeelenkapitaal te hebben opgewogen, terwijl de 32.000.000 doll. gewoon aandeelenkapitaal "good will", goede verwachtingen en oprichtingskosten vertegenwoordigden.

Genoegzaam gelijkluidend waren de getuigenissen betreffende de American Steel Hoop $C^{\circ}$ en de American Sheet Steel Co., 
van welke beide corporaties de pref. en gewone aandeelen ${ }_{n} \mathrm{a}$ pari overgingen in die der United States Steel Corporation.

Omtrent de Federal Steel $\mathrm{C}^{0}$ - waarvan de 53.260.900 doll. preferente aandeelen a $110 \mathrm{pCt}$. geconverteerd werden in nieuwe preferente aandeelen en de 46.484 .300 doll. gewone aandeelen 4 pCt. nieuwe preferente aandeelen en $107 \frac{1}{2}$ pCt. nieuwe gewone aandeelen bekwamen - werd alleen getuigd, dat het geheele kapitaal der corporatie, tezamen ruim 99 millioen doll., aangenomen kon worden als de tegen woordige waarde der onderscheidene installaties te vertegenwoordigen, ofschoon tot een bedrag van 31 millioen doll. dit niet bleek uit de boeken van de verschillende tot de corporatie behoorende maatschappijen.

Uit ardere bronnen kan omtrent deze corporatie nog het volgende worden vermeld. Bij hare oprichting werden in haar vereenigd de Minnesota Iron $\mathrm{C}^{\circ}$, de Illinois Steel $\mathrm{C}^{\circ}$ en de Elgin, Joliet \& Eastern Ry. Het aandeelenkapitaal dezer drie maatschappijen en de conversie daarvian in de Federal Steel $\mathrm{C}^{\circ}$ waren als volgt:

Aandeelenkapitaal der doll. waarvoor in ruil gegeven Aand. Federal S. Co tegen bijbetaling

\begin{tabular}{|c|c|c|c|c|}
\hline der & doll. & $\begin{array}{l}\text { doll. } \\
4.471500\end{array}$ & $\begin{array}{c}\text { doll. } \\
22.357 .500\end{array}$ & $\begin{array}{c}\text { doll. } \\
17.886 .000\end{array}$ \\
\hline Illinois S. Co & 18.656 .6 & 3.731 .320 & 18.656 .600 & 14.925 .280 \\
\hline E. J. \& E. Ry & 6.000 .000 & 1.050 .000 & 5.250 .000 & 4.200 .000 \\
\hline tezamen & 41.156 .600 & 9252.820 & 46.264 .100 & 37.011 .280 \\
\hline
\end{tabular}

Ten anzien van de American Steel \& Wire $C^{\circ}$ luidde de getuigenis, dat van het totale aandeelenkapitaal van 90.000.000 doll. niet meer dan 15 millioen doll. geacht moest worden voor "good will" uitgegeven te zijn. Hier kan weder bijgevoegd worden, dat de corporatie, opgericht 13 Januari 1899 onder de wetten van New Jersey, in zich opuam, nevens een aantal andere instellingen, de den $2^{\text {den }}$ April 1898 onder de wetten van Illinois opgerichte evenzoo genoemde American Steel \& Wire Co. Het kapitaal van deze had bestaan uit 12 millioen doll. preferente en gelijk bedrag gewone aandeelen. Het werd - na 9 maanden bestaan - in de aandeelen der nieuwe corporatie geconverteerd als volgt: 
onde maatschappij

doll.

Preferente aand. 12.000.000

Gewone

$$
\text { tezamen } \frac{12.000 .000}{24.000 .000}
$$

nieuwe corporatie

Pref. aand. Gew. and.

doll.

doll.

$12.000 .000 \quad 7.200 .000$

$\frac{\frac{\overline{1}}{12.000 .000} \frac{14.400 .000}{21.600 .000}}{33.600 .000 .}$

De Industrial Commission zegt naar aanleiding van de door haar ontrangen getuigenissen, daarbij aannemende dat de National Tube $\mathrm{C}^{\circ}$ in gelijke positie verkeerde als de American Tin Plate $\mathrm{C}^{0}$, dat dus volgens het eigen oordeel van bestuursledeu, welker voorstelling van den toestand zeker wel niet te ongunstig was, het totale bedrag van het aandeelenkapitaal der genoemde zeven corporaties, nevens een aangenomen verkoopswaarde harer gezamenlijke activiteiten van 298.570.200 doll., voor een bedrag van 158.500 .000 doll. louter "good will" vertegenwoordigde, welk bedrag in de United States Steel Corporation met 74.373.035 doll. verhoogd en dus tot 232.873.035 doll. aangegroeid is. En zoude aangenomen worden - luidt het verder in het rapport der commissie - dat het geheele gewone aandeelenkapitaal van al de in de United States Steel Corporation opgenomen tien oudere corporaties, met uitzondering nochtans van dat der Carnegie $C^{o}$ en van dat der Lake Superior C. I. M., omdat deze twee geen preferent aandeelenkapitaal hadden, slechts "good will" vertegenwoordigde, dan komt men hiervoor tot een bedrag van 270.935.100 doll., en hierbij dan nog tellende het bedrag der kapitaals vermeerdering welke door de United States Steel Corporation zelve geschiedde, tot een totaal bedrag van 390.341.111 doll, waarvoor tegenover het kapitaal dier nieuwe corporatie, slechts "good will" zou staan en materieele activiteiten zouden ontbreken. Ten andere echter aldus besluit de commissie hare beschouwingen over dit punt moet ook niet vergeten worden, dat de getuigenissen waarop de gemaakte berekeningen steunen, den stand van zaken betreffen zooals die twee jaar tevoren was; en volgens bestuursleden van de United States Steel Corporation zelve zouden sedert toen de activiteiten der gezamenlijke overgenomen corporaties met een bedrag van 175.000 .000 vermeerderd zijn.

Aangaande de Carnegie $C^{\circ}$ zelve werden, als reeds gezegd, 
aan de Industrial commission volstrekt geen mededeelingen gedaan, vok niet soortgelijke als die welke wij dar juist omtrent onderscheidene der andere corporaties vermeldden. Bekend is echter het volgende. De Carnegie $\mathrm{C}^{\circ}$, zooals zij laatstelijk bestond met een aandeelenkapitaal van 160.000 .000 doll. en een obligatienkapitaal van gelijk bedrag, dagteekende van 24 Maart 1900 en werd toen opgericht onder de wetten van den staat New Jersey. Aan har ging over het geheele aandeelenkapitaal van de, den $1^{\text {sten }} J u l i 1892$, onder de wetten van den staat. Pensylvanie opgerichte corporatie The Caruegie Steel $\mathrm{C}^{\circ}$, limited, die toen was opgevolgd aan Carnegie Bros en $\mathrm{C}^{\circ}$, limited, en alle fabrieken en andere bezittingen van deze vennootschap en van de firma Carnegie, Phipss en Co. had overgenomen. The Carnegie Steel $\mathrm{C}^{\circ}$., limited, was opgericht met uitsluitend een aandeelenkapitaal van 25.000.000 doll. Zoowel in deze maatschappij als in de haar opgevolgde Carnegie $\mathrm{C}$. bleef de bekende Andrew Carnegie, de stichter van de zakk, steeds houder van een overgroote meerderheid van het geheele kapitaal. Welke winsten gemaakt zijn werd nooit medegedeeld; maar wel is van algemeene bekendheid dat deze hoogst aanzienlijk waren men heeft beweerd dat in 1898-99 ze 70.000.000 doll. bedroegen - en voor het grooter deel werden aangewend tot uitbreiding. der zaak. Vandaar dan zeker ook de vermeerdering van het maatschappelijk kapitaal van 1892 tot 1900 van 25 op 320 millioen doll. en nu laatstelijk bij den overgang in de United States Steel Corporation op - obligatienkapitaal, preferent en gewone aandeelenkapitaal, alles te zamen - 4.96 millioen doll. Maar in hoever toch deze 496 millioen nu materieele activiteiten vertegenwoordigden en voor welk bedrag slechts "good will", dit blijft een vraag.

Zoover dan wat betreft het punt van de kapitalisatie der oude corporaties, voor zooveel ons daaromtrent gegevens ter dienste stonden, want - het is een algemeene grief tegen alle mogelijke corporaties - met mededeelingeu omtrent den eigenlijken stand van zaken zijn ze steeds bijzonder spaarzaam geweest.

Zien wij nu verder welke hare positie was vór de samensmelting tot de United States Steel Corporation.

Een hoogst belangrijk exposé daarvan is onlangs geleverd 
door prof. Edward Sherwood Meade van de Pensylvania-universiteit ${ }^{1}$ ).

Naar deze uiteenzet had de consolidatie-beweging in de ijzer- en staalindustrie der jaren 1898 tot 1900 de daarbij betrokken corporaties op hel einde van laatstgenoemd jaar in een zeer hachelijken toestand gebracht.

Haar krediet was geschokt, gelijk gebleken was uit de groote daling welke de prijzen der aandeelen ondervonden hadden. En hiertoe had, zegt de schr., ook alleszins reden bestaan. Opgericht met een anzienlijk aandeelenkapitaal, hadden de eirste winsten voor een groot deel aangewend moeten worden tot het vormen van krachtige reservefondsen of tot vermeerdering der activiteiten nevens afschrijving op de aangenomen waarde der ingebrachte. Doch daartoe kon niet overgegaan worden, omdat aan een deel van het aandeelenkapitaal het recht was toegekend op een cumulatief preferent dividend en zelfs voor het gewone aandeelenkapitaal het vooruitzicht was voorgespiegeld van onmiddellijk in het genot van dividenden te treden. Te minder, daarbij, wilde men er zich aan wagen de aandeelhouders teleur te stellen, omdat de aandeelen bij de oprichting voor een belangrijk deel in handen waren gekomen van bankierssyndicaten en aan deze de tijd gelaten moest worden en de gelegenheid gegeven, om ze aan het publiek over te plaatsen. In én woord, èn de samenstelling van het kapitaal der corporaties, èn de wijze der plaatsing daarvan, waren een oorzaak van innerlijke zwakte voor haar geworden ${ }^{2}$ ).

1) Zie het Augustus-nummer van The Quarterly Journal of Economics vari Harvard Unjversity.

$\left.{ }^{2}\right)$ Deze schr. maakt ten aanzien van de voorwaarde van cumulatie voor preferent dividend een opwerking die alle aandacht verdient. Schijnbaar, zegt hij, is ' $t$ alsof de uitgifte van een cumulatief preferent aandeelenkapitaal voor de gewone aandeelhouders voordeeliger is dan die van obligatienkapitaal. Maar in de werkelijkheid is het tegenovergestelde het geval. Het is al niet minder bezwaarlijk voor een maatschappij in gebreke to blijven met de uitbetaling van een cumulatief preferent dividend dan met die der rente van het obligatienkapitaal. Toch moet een veel hooger bedrag van preferent dividend beloofd worden dan de rente zou behooren te bedragen, waartoe een obligatien-leening te plaatsen ware geweest. Te recht, zegt hij, is dan ook door de spoorweg-maatschappijen met dien vorm van kapitaalsuitgifte reeds lang gebroken. 
In het geheel waren op het einde van 1900 , naar de schr. mededeelt, door de zes hieronder vermelde corporaties uit de winsten slechts de volgende sommen gereserveerd:

Gereserveerd Uitmakende over het doll. totale aand. kap.

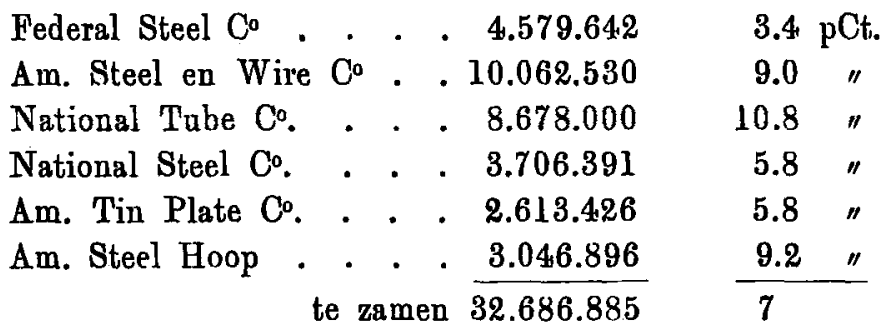

En wat beteekende, zegt hij, dit bedrag, daar van het gezamenlijk kapitaal van ruim 4,08 millioen meer dan 215 millioen slechts uit gewone aandeelen bestonden, die, ook volgens hem, geen materieele activiteiten vertegenwoordigden. Naar zijne opvatting moet bij deze corporaties het gewone aandeelenkapitaal eigenlijk beschouwd worden als de kapitalisatie der winst, welke juist verwacht wordt van de samenvoeging tot ééne onderneming van de verschillende daarbij betrokken bedrijven, behoudens het deel dat werd uitgegeven voor nieuw werkkapitaal. En al mochten nu ook belangrijke sommen besteed zijn voor verbetering der fabrieksinrichtingen - waartoe intusschen ook het nieuwe werkkapitaal gediend zou hebbeu de uitkomst was, dat op het eind van 1900 de corporaties niet beter gewapend waren tegen concurrentie van buitenaf dan bij hare oprichting, concurrentie ter welker bestrijding zij juist in de corporative conceutratie van bedrijven haar kracht hadden gezocht.

Toch werden zij nu door nienwe concurrentie bedreigd en dat wel in gevaarlijker vorm dan ooit te voren.

De acht corporaties, die tot de oorspronkelijke samenstelling van de United States Steel Corporation hebben medegewerkt, moeten in twee categorien verdeeld worden. Tot de eene behoorden de Carnegie $\mathrm{C}^{\circ}$, de Federal Steel $\mathrm{C}^{\prime \prime}$ en de National Steel $\mathrm{C}^{\circ}$, tot de andere de Natioual Tube $\mathrm{C}^{\circ}$, de American Steel and Wire $\mathrm{C}^{\circ}$, de American Tin Plate $\mathrm{C}^{\circ}$, de American Steel Hoop $\mathrm{C}^{\circ}$ en de American Sheet Steel Co. De laatstgenoemden waren hoofdzakelijk fabrikanten van bewerkt staal, de eerstgenoemden 
van het ruwe product. Onder elkander hadden zij het geheele veld van de ijzer- en staalindustrie verdeeld in verband met hare verschillende werkzaamheden en met de plaatselijke ligging harer inrichtingen, en dit ook wat betreft de levering van de producten der corporaties van de eene categorie aan die der andere.

Aanvankelijk uu, in de jaren 1898 en 1899 toen er groote levendigheid heerschte in de ijzer- en staalindustrie, ging alles goed. Ieder voor zich had volop werk en was tevreden met de uitkomsten. Maar in het voorjaar van 1900 trad reactie in op de markt der staalproducten, eene reactie die tot in November van dat jaar aanhield. Het werd duidelijk dat men zich algemeen met mindere winsten dan tevoren tevreden zou moeten stellen. Maar dit nu gedoogden de verplichtingen der corporaties tegenover hare aandeelhouders niet.

Een ieder voor zich werd daarom er op bedacht om in uitbreiding van het eigen veld van werkzaamheid en betreding daardoor van dat van een of anderen bondgenoot, het redmiddel uit den toestand te zoeken. Allerlei plannen van aankoop, eenerzijds van kolen- en ertsmijnen, anderzijds tot aanbouw van nieuwe fabrieken, alsook tot aanleg van nieuwe spoorweglijnen in verband met de uitbreiding der zelfstandige werkzaamheid der belanghebhenden, werden gevormd en bekwamen hier en daar ook reeds een begin van uitvoering.

Wij kunnen hier dit alles niet in bijzonderheden mededeelen ${ }^{1}$ ). Genoeg zij het te vermelden, dat het dreigend gevaar werd afgewend en het herstel der verbroken harmonie verkregen, doordat men besloot om tot de vroegere samenwerking terug te keeren. Thans echter werd daarvoor een vorm gekozen die het blijvend bestaan daarvan verzekeren zou, de vroegere corporaties-bondgenooten met de Carnegie Co voorop, nu allen vereenigd wordende in éćne nieuwe corporatie, de reuzencorporatie van 1901, de United States Steel Corporation.

Waren echter de verschillende industrieelen aan henzelven overgelaten gebleven, ' $t$ is de vraag of dit gelukt zou zijn. Maar achter hen stonden de groote financiers die belang hadden bij bet afwenden van den strijd en van de alsdan onvermijdelijke

1) In het genoemde artikel vau prof. Meade in het Quarterly Journal of Economies wordt daarvan een uitvoerig verhaal gegeven. Eoon. 1901. 
daling der fondsen van de oude corporaties. Zij hadden daarbij een direct belang ter wille van die fondsen zelven, en bovendien een indirect belang met het oog op andere financieele operatien van grooten omvang welke in die dagen beraamd werden. Zij traden daarom als de bemiddelaars tusschen de verschillende partijen op en wisten ze voor het nieuwe bondgenootschap te winnen.

Door overreding alleen? Of ook door met groote stoutmoedigheid - de omstandigheden van den dag, de groote algemeene willigte welke zich aan de Newyorker beurs was beginnen te openbaren, daartoe de gelegenheid openende - aan de ineensmelting der oude corporaties groote kapitaalsuitbreiding te verbinden?

Hoe dit zij, het beginsel, dat aan de nieuwe en nu op nog zooveel grooter schaal dan te voren uitgevoerde aaneensluiting ten grondslag lag, was weder geen ander dan dat door vereeniging van verschillende bedrijven tot ééne onderneming de voortbrengingskosten verminderd, de voortbrengingsvoorwaarden verbeterd werden.

Onderzoeken wij dan thans nader wat eigenlijk hiermee bedoeld wordt, of inderdaad dit beginsel degelijken grondslag heeft, en of tegenover de beweerde voordeelen, indien of voorzooveel ze bestaan, geen andere nadeelen staan.

Hierover in een volgend stuk.

E6ne opmerking kunnen wij echter reeds thans ons niet weerhouden te maken. Aangenomen dat werkelijk door de vereeniging van verschillende bedrijren tot éne onderneming groote besparing der voortbrengingskosten wordt verkregen, dan zal toch, wanneer iedere aaneensluiting slechts gepaard kan gaan, ten minste gepaard gaat, met nominale kapitaalsvermeerdering, het gevaar groot zijn dat er naar gestreefd worde dit voordeel uitsluitend te exploiteeren ten bate der aandeelhouders, in plaats van het ten goede te laten komen aan de consumenten van het nijverheidsproduct of aan de arbeiders door loonsverhooging.

October 1901.

G M. Boissevain. 